\title{
Association Between Cardiothoracic Ratio and Mortality in Neonates with Pneumothorax
}

\author{
Pnömotorakslı Yenidoğanlarda Kardiyotorasik Oran ve Mortalite Arasındaki İlişki \\ ๑ Fatma Hilal Yılmaz, ๑ Nuriye Emiroğlu Tarakçı, ๑ Nazlı Dilay Gültekin, • Ümit Gültekin*, \\ (1) Hüseyin Altunhan
}

Necmettin Erbakan University Meram Faculty of Medicine, Department of Neonatology, Konya, Turkey

${ }^{*}$ Necmettin Erbakan University Meram Faculty of Medicine, Department of Pediatrics, Konya, Turkey

\section{Abstract}

Aim: The aim of this study was to determine the effect of a reduction in the cardiothoracic ratio (CTR) on mortality in newborns with pneumothorax.

Methods: Newborns with pneumothorax, who were admitted to our neonatal intensive care unit, were included in the study. The cardiothoracic ratio was calculated by dividing the transverse cardiac diameter by maximum internal thoracic diameter.

Results: Of 7909 infants admitted to our neonatal intensive care unit from September 2006 to September 2017, a total of 82 (1.03\%) newborns had pneumothorax. Patients who died had a lower CTR than surviving patients $(0.39 \pm 0.056$ and $0.44 \pm 0.048$, respectively; $p<0.001)$. It was found that the cut-off value was 0.4 , area under the curve (AUC) value was 0.79 , sensitivity was $68 \%$, specificity was $87.7 \%$, positive predictive value was $70.8 \%$, and negative predictive value was $86.2 \%$. Low birth weight, preterm birth, low maternal age, presence of respiratory distress syndrome, need for resuscitation at birth, and invasive mechanical ventilation were found to be significantly associated with mortality. However, among overall significant parameters, CTR and implementation of resuscitation at birth were the independent prognostic factors determined by regression analysis ( $p=0.001$ and $p=0.036$, respectively).

Conclusion: A CTR below $0.4 \%$ can be considered an important parameter indicating an increased risk of mortality in newborns with pneumothorax.

Keywords: Neonatal pneumothorax, cardiothoracic ratio, mortality, morbidity
Amaç: Bu çalışmanın amacı pnömotoraks gelişen yenidoğan hastalarda kardiyotorasik oran (KTO) azalma oranının mortaliteyi belirleme üzerine etkisinin ortaya konulmasıdır.

Yöntemler: Yenidoğan yoğun bakım ünitemize pnömotoraks ile takip edilen yenidoğan bebekler çalışmaya dahil edildi. Kardiyotorasik oran hesabı göğüs grafisinden mediastenin ortasından çizilen dikey bir çizgiye kalbin en sağ ve en sol noktasından çizilen dik çizgilerin toplamları, diyafragmaya teğet olarak çizilip kostaların iç sınırlarına kadar uzanan toraks çapına bölünerek bulundu.

Bulgular: Eylül 2006'dan Eylül 2017 tarihleri arasında yenidoğan yoğun bakım ünitesine 7909 bebek başvurdu, 82'sinde $(\% 1,03)$ pnömotoraks gelişti. Genel mortalite oranı \%30 idi. Ölen hastalar, hayatta kalanlara göre daha düşük KTO'ya sahiptiler (sırasıyla, $0,39 \pm 0,056$ ve $0,44 \pm 0,048, p<0001)$. Cut-off değeri 0,4 , eğri altında kalan (AUC) değeri 0,79, duyarlılık \%68, özgüllük \%87,7, pozitif öngörü değeri \%70,8, negatif öngörü değeri \%86,2 olarak bulundu. Düşük doğum ağırlığı, preterm doğum, düşük maternal yaş, RDS varlığı, doğumda resüsitasyon ihtiyacı ve invaziv mekanik ventilasyonun mortalite ile anlamlı derecede ilişkili olduğu bulunmuştur. Bununla birlikte, genel anlamlı parametreler arasında, KTO ve doğumda resüsitasyonun uygulanması, regresyon analizi ile bağımsız prognostik faktörlerdir (sırasıyla, $p=0,001$ ve $p=0,036$ ).

Sonuç: Pnömotorakslı yenidoğanlarda KTO'nun 0,4'ün altında olması mortalite riskinin arttığını gösteren önemli bir parametre olarak kabul edilebilir.

Anahtar Sözcükler: Neonatal pnömotoraks, kardiyotorasik oran, mortalite, morbidite
Address for Correspondence/Yazıșma Adresi: Fatma Hilal Yılmaz, Necmettin Erbakan University Meram Medical Faculty, Department of Neonatology, Konya, Turkey E-mail: f.h.yilmaz@hotmail.com ORCID: orcid.org/0000-0002-1152-9773

Received/Geliş Tarihi: 25 September 2018 Accepted/Kabul Tarihi: 25 September 2018
${ }^{\circ}$ Copyright 2019 by The Medical Bulletin of istanbul Haseki Training and Research Hospital The Medical Bulletin of Haseki published by Galenos Yayınevi.

${ }^{\circledR}$ Telif Hakkı 2019 istanbul Haseki Eğitim ve Araştırma Hastanesi Haseki Tıp Bülteni, Galenos Yayınevi tarafından yayınlanmıştır. 


\section{Introduction}

Air-leak syndromes are more common in the neonatal period than in other periods of life. During this period, pneumothorax, one of the air-leak syndromes, is the most commonly observed condition (1). Pneumothorax is a serious cause of mortality and morbidity in newborns (2). Although the incidence of pneumothorax varies with underlying lung disease, low birth weight, and methods used for diagnosis, it is seen in 1-2\% of full-term live births according to recent data. However, this rate has reached $4.1 \%$ for preterm babies with a birth weight of 500-1500 grams $(3,4)$. There are also studies showing increased risk of development of chronic pulmonary disease and mortality in preterm infants with air leak (5).

Cardiothoracic ratio (CTR) is obtained by dividing the transverse cardiac diameter by the maximum internal thoracic diameter (6). It was first described by Danzer (7). CTR values above 0.5 in children older than 3 years and adults and above 0.60-0.65 in newborns indicate cardiomegaly. CTR that is a simple and inexpensive tool used for predicting heart size can be affected by respiratory phase, cardiac cycle, structural changes of the thorax (such as scoliosis and pectus excavatum), and lung width (8). We saw that the lungs that were suppressed with air leak pressed the heart, and for this reason, CTR became smaller in newborn patients with pneumothorax whose lung graphics we evaluated. We aimed to reveal the relationship between CTR and mortality based on the prediction that it is the indicator of hemodynamic effect in an indirect way. We thought that this practical computation would give an idea to the clinician in case a relationship was detected.

This study was conducted at Necmettin Erbakan University Meram Faculty of Medicine, third Stage Newborn Unit. The rate of mortality in the unit is approximately $5 \%$ and the most frequent mortality reason is sepsis. The aim of this study was to determine the effect of a reduction in the CTR on mortality in newborn patients with pneumothorax.

\section{Methods}

\section{Participants}

An observational, analytical design was used in the study. This study was conducted on consecutive newborns who developed pneumothorax between September 2006 and September 2017 in the Neonatal Intensive Care Unit, Meram Faculty of Medicine, Necmettin Erbakan University.

\section{Procedures}

Data were obtained from electronic medical records and patients' files. The information was recorded in preformed forms. Gestational week, gender, type of delivery, birth weight, history of cardiopulmonary resuscitation after birth, surfactant application, presence of spontaneous pneumothorax and underlying lung disease [respiratory distress syndrome (RDS), meconium aspiration syndrome (MAS), pneumonia, and transient tachypnea (TTN) of the newborn], day of pneumothorax, side of pneumothorax, duration of chest tube drainage, invasive/non-invasive mechanical ventilation, and intubation period were recorded. In addition, their relationships with mortality were also evaluated.

Except for patients who developed pneumothorax after surgery such as patent ductus arteriosus ligation and who had a chest drain connected to underwater seal drainage which did not run and/or required a further revision, all patients with pneumothorax were included in the study. Pneumothorax was diagnosed by chest X-ray.

The CTR was calculated by dividing the transverse cardiac diameter [sum of the horizontal distances from the right and left lateral-most margins of the heart to the midline (spinous processes of the vertebral bodies)] by the maximum internal thoracic diameter (9). The measurements were made by one specialist and the confirmatory measurements were made by another specialist. The results were similar in $99.2 \%$ of measurements.

\section{Ethical aspects}

The study was approved by the Ethics Committee of Necmettin Erbakan University (no: 2017/1117).

\section{Statistical Analysis}

The SAS University Edition 9.4 was used for the statistical analysis of the data obtained in the study. Descriptive statistics for continuous variables were expressed as mean \pm standard deviation or median (Q1-Q3). Continuous variables were compared using the Student's t-test or the Mann-Whitney $U$ test. Categorical variables were given as frequency and percentage and were compared using the chi-square test. A p-value of less than 0.05 was considered statistically significant.

A receiver-operator characteristic ( $R O C$ ) curve was used to explore the diagnostic ability of CTR. The cut-off value was calculated using the Youden index and corresponding sensitivity, specificity, positive predictive value (PPV); and negative predictive value were also calculated. The Firth's Logistic Regression model was performed to model mortality. Odds ratios and confidence intervals were also given.

A classification tree for mortality was obtained by using the Weka 3.9.1 Program with 10-fold cross-validation. Classification and regression trees (CART) is a machine 
learning method for constructing predictive models from data. The models are obtained by recursively partitioning

the data space and fitting a simple prediction model within each partition. As a result, the partitioning can be represented graphically as a decision tree. It acts as a predictive model as well as a fine-tuned description of the data.

\section{Results}

Pneumothorax was detected in 82 of 7909 patients $(1.03 \%)$ who were admitted to our neonatal intensive care unit during an 11-year period. The demographic data of the patients are given in Table 1.

While $55(67 \%)$ patients had underwater seal chest tubes inserted, seven (8.5\%) patients underwent needle aspiration. However, 20 (24.3\%) patients were followed without any intervention. The mean chest tube duration was $4.85 \pm 3.77$ days.

Eighty-one $(98.7 \%)$ patients had an underlying cause for pneumothorax whereas only one (1.2\%) patient had spontaneous pneumothorax. Of the patients having an underlying cause, 34 (41.9\%) had RDS, eight (9.87\%) had MAS, 13 (16\%) had congenital pneumonia, and 26 (32\%) had TTN.

Surfactant was administered to 25 (30.48\%) of the 34 patients with RDS; and 35 (42.68\%) patients were resuscitated in the delivery room. A total of 34 (41.46\%) patients received continuous positive airway pressure (CPAP) therapy for pneumothorax; and 56 (68.29\%) patients received mechanical ventilation after pneumothorax.

Twenty-five (30.48\%) patients died. The patients who died were compared with surviving patients in terms of some parameters. The results are summarized in Table 2 .

According to the ROC analysis, it was found that the cut-off value was 0.4 , AUC value was 0.79 , sensitivity was $68 \%$, specificity was $87.7 \%$, positive predictive value was $70.8 \%$, and negative predictive value was $86.2 \%$ (Figure 1). There was a significant difference in CTR between patients with and without RDS (mean CTR $=0.44 \pm 0.05$ and $0.41 \pm 0.06$, respectively $p=0.039$ ).

The association of mortality with early CPAP implementation in the delivery room was compared with the association of mortality with CPAP therapy and invasive mechanical ventilation, and mechanical ventilation applications after transfer to the hospital ward with only free oxygen. We observed that mechanical ventilation in the neonatal intensive care unit was associated with a statistically significant increase in mortality $(p=0.33$, $p=0.79$ and $p=0.011$, respectively).

When the Firth's Logistic Regression Analysis was performed by including RDS, need for resuscitation at birth, CTR and CPAP therapy, the CTR and resuscitation were found to be statistically significant. The odds ratio for the CTR and resuscitation was $8.14(2.30-28.74 p=0.001)$ and $0.86(0.75-0.99 p=0.036)$, respectively. Other odds ratios are given in Table 3. A classification tree for mortality was obtained by using Weka 3.9.1 Program with 10-fold cross-validation (Figure 2).

\section{Discussion}

This study was carried out to investigate whether CTR had a definitive role in mortality and survival in newborns with pneumothorax who were followed up in our medical center.

When compared with studies conducted on newborns with pneumothorax, our patients were mostly preterm, consistent with the literature data. The number of the male patients was higher than females, which is similar to the data of other studies. It is noteworthy that caesarian birth rates were higher, which is similar to the previous

\begin{tabular}{|c|c|c|}
\hline & $\mathbf{n}$ & $\%$ \\
\hline $\begin{array}{l}\text { Gender } \\
\text { Male } \\
\text { Female }\end{array}$ & $\begin{array}{l}56 \\
26\end{array}$ & $\begin{array}{l}68.30 \\
31.70\end{array}$ \\
\hline $\begin{array}{l}\text { Duration of gestation } \\
\text { Preterm } \\
\text { Term }\end{array}$ & $\begin{array}{l}49 \\
33\end{array}$ & $\begin{array}{l}59.76 \\
40.24\end{array}$ \\
\hline $\begin{array}{l}\text { Type of delivery } \\
\text { Vaginal } \\
\text { Cesarean (C/S) }\end{array}$ & $\begin{array}{l}16 \\
66\end{array}$ & $\begin{array}{l}19.50 \\
80.50\end{array}$ \\
\hline $\begin{array}{l}\text { Birth weight (gr) } \\
\quad<2500 \\
2500\end{array}$ & $\begin{array}{l}41 \\
41\end{array}$ & $\begin{array}{l}50.0 \\
50.0\end{array}$ \\
\hline $\begin{array}{l}\text { Pneumothorax location } \\
\text { Bilateral } \\
\text { Right } \\
\text { Left }\end{array}$ & $\begin{array}{l}21 \\
37 \\
24\end{array}$ & $\begin{array}{l}25.60 \\
45.10 \\
29.30\end{array}$ \\
\hline Resuscitation at birth & 35 & 42.68 \\
\hline Surfactant therapy & 25 & 30.48 \\
\hline RDS presence & 34 & 41.46 \\
\hline Mortality & 25 & 30.48 \\
\hline Patients with CPAP & 34 & 41.46 \\
\hline \multirow[t]{2}{*}{ Mechanical ventilation } & 56 & 68.29 \\
\hline & Mean \pm SD & $\min -\max$ \\
\hline Birth weight (gr) & $2369.42 \pm 925.33$ & $(540-4250)$ \\
\hline Gestational age (week) & $34.56 \pm 4.26$ & $(24-41)$ \\
\hline \multirow[t]{2}{*}{ Mother's age } & $27.46 \pm 5.58$ & $(17-41)$ \\
\hline & Median (Q1-Q3) & \\
\hline $\begin{array}{l}\text { Pneumothorax diagnosis time } \\
\text { (day) }\end{array}$ & $2(1-3)$ & $(1-18)$ \\
\hline
\end{tabular}


studies conducted in the same field. We saw that air leak was more common in the right lobe of the lung, which was also reported in the study conducted by Katar et al. (12).

Pneumothorax, which often occurs secondary to an underlying lung pathology or mechanical ventilation in the neonatal period, causes mortality and morbidity as well as severe respiratory distress. In two studies conducted in Turkey, mortality rates for pneumothorax were reported as $38.5 \%$ and $30 \%(10,11)$. The incidence of pneumothorax

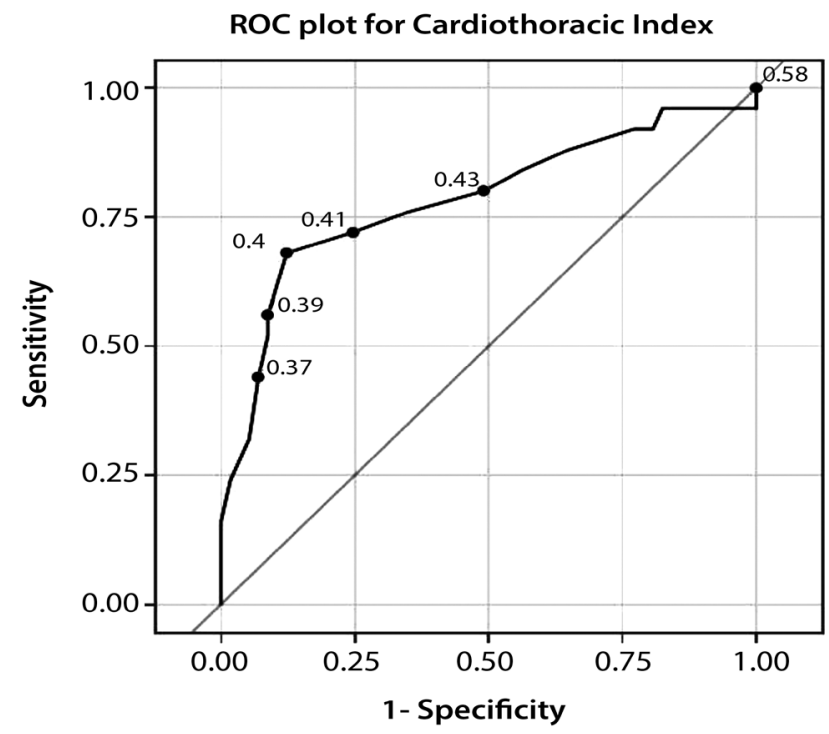

Figure 1. Calculation of Cardiothoracic ratio under ROC curve (Cardiothoracic ratio AUC $(0,79)$ Sensitivity \%68, Specificity \%87.7, cut-off 0.4, PPV \%70.8, NPV \%86.2)

PPV: Positive pressure ventilation, NPV: Negative pressure ventilation, ROC: Receiver operating characteristic, AUC: Area under a curve in our neonatal intensive care unit was $1.03 \%$. Our mortality rate $(30 \%)$ was found to be consistent with the data reported for the last four decades in the literature $(2,12,13)$.

\begin{tabular}{|c|c|c|c|}
\hline & $\begin{array}{l}\text { Survivors } \\
(\mathrm{n}=57)\end{array}$ & $\begin{array}{l}\text { Non-survivors } \\
(n=25)\end{array}$ & p \\
\hline $\begin{array}{l}\text { Gestational age } \\
\text { (week) }\end{array}$ & $37 / 20$ & $19 / 6$ & 0.441 \\
\hline Birth weight (gr) & $2538.25 \pm 799.94$ & $1993.76 \pm 1071.71$ & 0.013 \\
\hline $\begin{array}{l}\text { Gestational age } \\
\text { (week) }\end{array}$ & $35.34 \pm 3.38$ & $32.96 \pm 5.47$ & 0.053 \\
\hline Mother's age & $28.43 \pm 5.57$ & $24.69 \pm 4.78$ & 0.036 \\
\hline $\begin{array}{l}\text { Type of delivery } \\
\text { (vaginal vs } \mathrm{C} / \mathrm{S} \text { ) }\end{array}$ & $10 / 47(\% 82.5)$ & $6 / 19(\% 76.0)$ & 0.554 \\
\hline $\begin{array}{l}\text { Resuscitation at } \\
\text { birth }\end{array}$ & $15(\% 26)$ & $20(\% 80)$ & $<0.001$ \\
\hline Surfactant therapy & $15(\% 26.3)$ & $11(\% 44.0)$ & 0.11 \\
\hline $\begin{array}{l}\text { Pneumothorax } \\
\text { diagnosis time } \\
\text { (day) }\end{array}$ & $2(1-3)$ & $1(1-3)$ & 0.570 \\
\hline RDS presence & $19(\% 33.3)$ & $15(\% 60)$ & 0.02 \\
\hline $\begin{array}{l}\text { Mechanical } \\
\text { ventilation }\end{array}$ & $34(\% 59.6)$ & $22(\% 88.0)$ & 0.011 \\
\hline $\begin{array}{l}\text { Patients with } \\
\text { CPAP }\end{array}$ & $26(\% 46.4)$ & $8(\% 32)$ & 0.22 \\
\hline $\begin{array}{l}\text { CPAP and } \\
\text { Mechanical } \\
\text { ventilation } \\
\text { Cardiothoracic } \\
\text { ratio }\end{array}$ & $\begin{array}{l}15(\% 26.8) \\
0.44 \pm 0.048\end{array}$ & $\begin{array}{l}6(\% 24.0) \\
0.39 \pm 0.056\end{array}$ & $\begin{array}{l}0.79 \\
0.001\end{array}$ \\
\hline
\end{tabular}

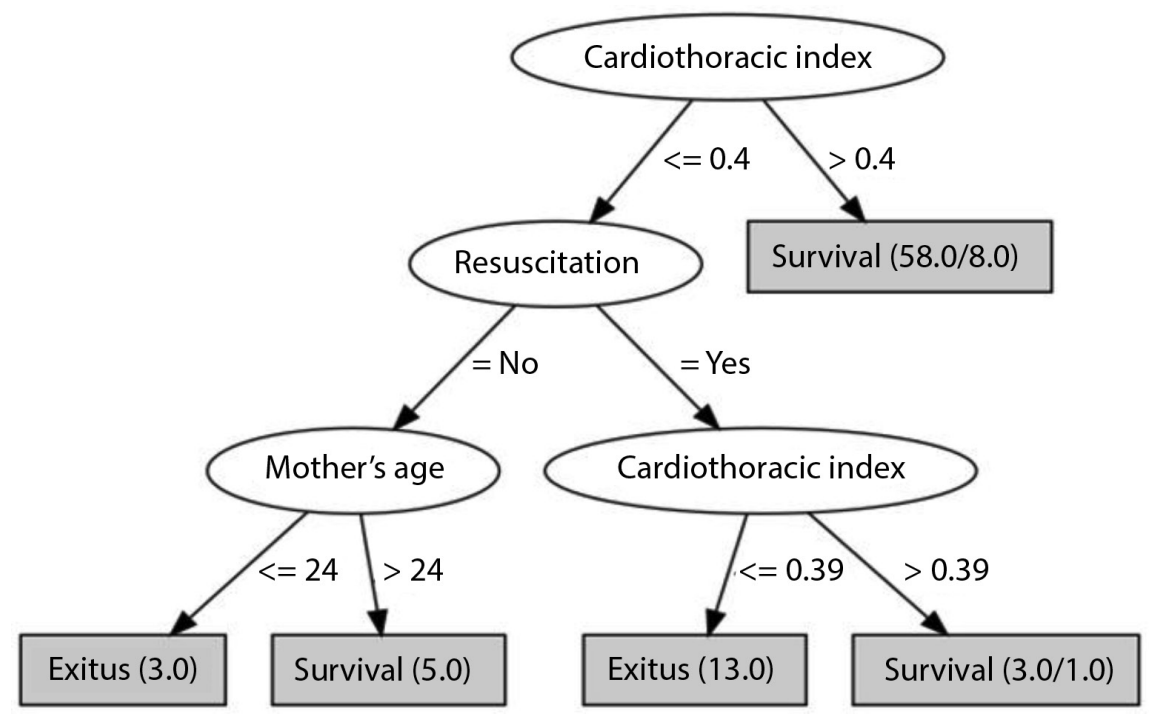

Figure 2. A classification tree for mortality 


\section{Table 3. Firth Logistic Regression Analysis results}

\begin{tabular}{|l|l|l|l|}
\hline & OR & $\begin{array}{l}\text { Confidence } \\
\text { Interval (\%95) }\end{array}$ & $\mathbf{p}$ \\
\hline Cardiothoracic ratio (in percent) & 0.86 & $0.75-0.99$ & 0.036 \\
\hline Resuscitation & 8.14 & $2.30-28.74$ & 0.001 \\
\hline RDS & 2.73 & $0.80-9.28$ & 0.11 \\
\hline CPAP & 0.31 & $0.09-1.14$ & 0.08 \\
\hline
\end{tabular}

RDS: Respiratory distress syndrome, CPAP: Continuous positive airway pressure, OR: Odds ratio

It has been reported in the literature that the disease is more common in male infants, preterm infants and postmature infants (14). Consistent with the literature, the majority of our patients were male and preterm infants. Elective caesarean section in term and preterm infants increases the tendency to RDS and TTN and thus the risk of pneumothorax (15). Most of our patients were delivered by C-section. Pneumothorax often occurs in preterm infants due to many causes such as decreased lung compliance and mechanical ventilation applications frequently used in the management of immature lung (16). Most of our patients were preterm infants. It has been shown in the literature that the mortality rate was high in preterm and low birth weight infants $(16,3)$. Our study also supports the literature.

The incidence of pneumothorax increases in the presence of lung pathologies such as respiratory distress, MAS, congenital pneumonia, TTN and pulmonary hypoplasia (17). It has been reported in the literature that there were underlying diseases such as pneumonia, meconium aspiration, mechanical ventilation or congenital lung anomalies in 59-61\% of newborns with pneumothorax (2). In our study, while TTN was more common in term infants, RDS was more frequently seen in preterm infants. We believe that the fact that TTN was more common in term infants is related to the higher rate of elective C-sections.

Supporting patients with invasive or non-invasive mechanical ventilation has been associated with pneumothorax. Morley et al. (17) reported that the incidence of pneumothorax after CPAP therapy was 9\%. In terms of the rate of our patients receiving CPAP therapy who developed pneumothorax during this period, there was no direct relationship between CPAP therapy and mortality.

However, we also compared the association of mortality with early CPAP implementation in the delivery room, receiving CPAP therapy, invasive mechanical ventilation, and mechanical ventilation applications after transfer to the hospital ward with only free oxygen. We observed that mechanical ventilation application in the neonatal intensive care unit was associated with a statistically significant increase in mortality $(p=0.33, p=0.79$ and $p=0.011$, respectively). In the literature, we did not find a difference in such a way as to support the results showing no relationship between early CPAP implementation and pneumothorax (18).

In the literature, resuscitation after birth was associated with pneumothorax (19). The rate of resuscitation in our patients was not higher, however, it was observed that implementation of resuscitation was statistically significantly associated with mortality. We observed that the mortality rate increased in those with low maternal age among surviving patients and those who died. We attributed this to the fact that low maternal age increases preterm birth rate. This brings other risk factors for pneumothorax such as need for resuscitation at birth, RDS, and low birth weight.

In pneumothorax, the mediastinum is displaced to the opposite side by increased intrapleural pressure. This mediastinal shift can cause a compression in the inferior vena cava and thus may lead to decreased venous return to the heart. CTR decreases with the compression of the heart within the thorax. Based on this information, we observed that the CTR was statistically significantly lower in patients who died when this ratio was compared between surviving patients and those who died. In our study, there was a significant association between low CTR and mortality. We found that the mortality rate was high in patients having values below this cut-off when the cut-off value of the CTR was accepted as 0.4. Özer et al. (11) found that pneumothorax size was significantly higher in patients who died than in surviving patients, and that a large-size pneumothorax was associated with poor prognosis. However, according to our knowledge, there is no such study in the English literature showing a relationship between CTR and mortality.

Ito et al. (9) found a relationship between increased CTR (>0.5) and mortality in hemodialysis patients. Similarly, there are studies in the literature showing a significant relationship between high CTR and prognosis. However, for the first time, the result pointed out by low CTR was evaluated in our study. This sensitivity and specificity measurement have not been used for this purpose in the literature before.

In our study, we found that the CTR was lower in the patients with pneumothorax caused by RDS. This is probably due to the fact that higher settings of mechanical ventilator due to decreased lung compliance with increased intrathoracic pressure in RDS increase the risk of pneumothorax and reduce the CTR (20). Furthermore, presence of RDS in patients with pneumothorax statistically significantly affects mortality. 


\section{Conclusion}

In our study, it is possible to argue that CTR is related to survival in patients with pneumothorax. We think that it can provide an opinion to clinicians about the prognosis during follow-up because it is easy to apply and is also reliable. A CTR below $0.4 \%$ in newborn patients with pneumothorax can be considered an important parameter indicating an increased risk of mortality. Prospective studies are needed to explain the relationship between CTR and mortality in patients with pneumothorax.

\section{Authorship Contributions}

Concept: F.H.Y. Design: F.H.Y., N.D.G. Data Collection or Processing: F.H.Y., Ü.G. Analysis or Interpretation: F.H.Y., N.E.T. Literature Search: F.H.Y., H.A. Writing: F.H.Y.

Conflict of Interest: The authors report no conflicts of interest. The authors alone are responsible for the content and writing of this article.

Financial Disclosure: The authors reported that this study received no financial support.

\section{References}

1. Jeng MJ, Lee YS, Tsao PC et al. Neonatal air leak syndrome and the role of high-frequency ventilation in its prevention. J Chin Med Assoc 2012;75:551-9.

2. Edwards MO, Kotecha SJ, Kotecha S. Respiratory distress of the term newborn infant. Paediatr Respir Rev 2013;14:29-36; quiz 36-7.

3. Terzic $S$, Heljic $S$. Assessing mortality risk in very low birth weight infants. Med Arh. 2012;66:76-9.

4. Al Tawil K, Abu-Ekteish FM, Tamimi O, et al. Symptomatic spontaneous pneumothorax in term newborn infants. Pediatr Pulmonol 2004;37:443-6.

5. Powers WF, Clemens JD. "Prognostic implications of age at detection of air leak in very low birth weight infants requiring ventilatory support." J Pediatr 1993;123:611-7.

6. Inouea K, Yoshiib K, Itob H. Effect of Aging on Cardiothoracic Ratio in Women: A Longitudinal Study. Gerontology 1999;45:53-8.

7. Danzer CS. The cardiothoracic ratio. An index of cardiac enlargement. Am J Med Sci 1919;157:513-21.
8. Hada Y. Cardiothoracic ratio. J Cardiol 1995;26:51-4.

9. Ito K, Ookawara S, Ueda $Y$ et al. A Higher Cardiothoracic Ratio Is Associated with 2-Year Mortality after Hemodialysis Initiation. Nephron Extra 2015;19:100-10.

10. Ilçe Z, Gündogdu G, Kara C et al. "Which patients are at risk? Evaluation of the morbility and mortality in newborn pneumothorax." Indian Pediatr 2003;40:325-8.

11. Ozer EA, Ergin AY et al. Is pneumothorax size on chest x-ray a predictor of neonatal mortality? Iran J Pediatr 2013;23:541-5.

12. Katar S, Devecioğlu C, Kervancioğlu M. Symptomatic spontaneous pneumothorax in term newborns. Pediatr Surg Int 2006;22:755-8.

13. Ogata ES, Gregory GA, Kitterman JA, et al. Pneumothorax in the respiratory distress syndrome: incidence and effect on vital signs, blood gases and pH. Pediatrics 1976;58:177-83.

14. Stoll BJ, Kliegman RM. Extrapulmonary extravasation of air. In: Behrman RE, Kliegman RM, Jenson HB (eds). Nelson Textbook of Pediatrics. 17th ed. Philadelphia: WB Saunders, 2004:586-7.

15. Kolas T, Saugstad OD, Daltveit AK, et al. Planned cesarean versus planned vaginal delivery at term: comparison of newborn infant outcomes. Am J Obstet Gynecol 2006;195:1538-43.

16. Horbar JD1, Badger GJ, Carpenter JH et al. Trends in mortality and morbidity for very low birth weight infants, 1991-1999. Pediatrics 2002;110 (1 Pt 1):143-51.

17. Morley CJ1, Davis PG, Doyle LW et al." Nasal CPAP or intubation at birth for very preterm infants." N Engl J Med 2008;358:700-8.

18. Ceylan A, Gezer S, Demir N. The importance of administration of early surfactant and nasal continuous positive airway pressure in newborns with respiratory distress syndrome. Turk Pediatri Ars 2014;49:192-7.

19. Malek A, Afzali N, Meshkat M, et al. Pneumothorax after mechanical ventilation in newborns. Iran J Pediatr 2011;21:4550.

20. Wambach AJ, Hamvas A. Respiratory Distress Syndrome in the Neonate. In: By Martin RJ, Fanaroff AA and Walsh MC (eds). Fanaroff and Martin's Neonatal-Perinatal Medicine, 2-Volume Set: Diseases of the Fetus and Infant. 10th ed. 2015:1074-86. 